\title{
The Internationalization of Islamic Banking and Finance: The Co-Evolution of Institutional Changes and Financial Services Integration
}

\author{
Juan-José Durán ${ }^{1} \&$ María-José García-López ${ }^{2}$ \\ ${ }^{1}$ Facultad de Ciencias Económicas y Empresariales, Universidad Autónoma de Madrid, Madrid, Spain \\ ${ }^{2}$ Facultad de Ciencias Jurídicas y Sociales, Universidad Rey Juan Carlos, Madrid, Spain \\ Correspondence: María-José García-López, Edificio Departamental, Facultad de Ciencias Jurídicas y Sociales, \\ Universidad Rey Juan Carlos, Paseo de Artilleros, s/n. 28032 Madrid, Spain. Tel: 34-670-994-532 or \\ 34-914-887-561. E-mail: mariajose.garcia@urjc.es
}
Received: May 16, 2012
Accepted: June 8, 2012
Published: July 1, 2012
doi:10.5539/ijbm.v7n13p49
URL: http://dx.doi.org/10.5539/ijbm.v7n13p49

\begin{abstract}
The basis for Islamic finance lies in the Shariah. In this paper we point out the co-evolution of institutional change and the banking expansion in Islamic countries; there are certain parallelism between the quantitative and qualitative developments of the Islamic financing industry and the emergence of supportive institutions. There are certain convergences of Islamic banking products and institutions towards traditional banking functioning but keeping their principles. The Islamic financial institutions are effective instruments towards financial and economic integration at regional and global level. The Islamic economy has also showed a lesser impact of the global crisis than the western economy.
\end{abstract}

Keywords: international Islamic finance, international Islamic banking, Islamic institutional environment

\section{Introduction}

Islamic law is at once ancient and modern. Islamic finance was practiced predominantly in the Muslim world through the middle ages. However, its application to banking has been witnessed only in the past 40 years(Note 1). It was only in the early 1970s, when it really gains significance, especially after the launch of the First International Conference on Islamic Economics and the establishment of the first commercial Islamic Bank, Dubai Islamic Bank (DIB) in the United Arab Emirates. After this event the international Islamic Development Bank (IDB) was established (in 1975) as well as many private and semi-private commercial Islamic banks that were opened, mostly in Egypt, Sudan, Kuwait and Bahrain. However, in a systematic way it appears only in the mid-1980s

Market mechanism, self-interest, private property, enterprises and profit motivation are pillars of the Islamic economic scheme, but the actions through these variables have to be taken looking for moral principles and values. Halal (permissible) and Haram (forbidden) provide a moral filter for all human actions. The economic system of Islam incorporates as a pillar Zakat, a religious rate (2.5-3.0\%) in favor of the poor people. The religious basic community is named UMMA.

The basis for all Islamic finance lies in the principles of the Shariah, or Islamic Law. Central to Islamic finance is the fact that money itself has no intrinsic value. As a matter of faith, a Muslim cannot lend money to, or receive money from someone and expect to benefit: interest (known as riba) is not allowed. To make money from money is forbidden - wealth can only be generated through legitimate trade and investment in assets. Money must be used in a productive way. Islamic believe that instead of a fixed reward there will be a variable reward based on actual return. In this sense in the Islamic system depositors are entitled to share the bank's net profit (or loss) according to the profit-loss-sharing (PLS) ratio stipulated in their contracts. In case of loss the quantity of the deposits can be reduced. Depositors then are somehow like shareholders, who earn profit when the bank turns a profit and lose a part of their savings if it posts a loss. However, depositors do not have voting right and they do not own any part of the equity of the bank. 
Financial contracts are base on a PLS principle. Profit sharing is an incentive for both the borrower and the lender to work together to ensure the success of its business venture. Under this idea financing can be equally available to anyone with a productive project. Thus the return of financial and real capital financed will depend both on productivity and on the soundness of the project. The Islamic financial system facilitates lending, borrowing and investment functions on a risk-sharing basis. This allows market forces to determine the productivity of capital rather than fixing it in priori basis as an "interest rate" through the free market mechanism that encourage speculative use and hoarding of capital. The Islamic financial system is linked to capital formation and its efficient utilization leading to a sustainable economic growth and fair opportunities for all. Then, under this conception Islam would prefer to promote an equity-based, risk sharing, and stake-taking economic system to a debt-based system .Capital and entrepreneurs are both entitled to share from the profit (Ahmed, 2002). It is a value-based system that primarily aims at ensuring moral and material wellbeing of the individual and society as a whole (Zarqa, 1983; Ahmed, 1994).

Though representing only a small portion of the global assets, the Islamic finance market has been growing over $20 \%$ annually and is set for continued growth. The Banker's 2009 survey of Islamic finance found the volume of Shariah (Islamic law)-compliant assets of the Top 500 banks grew by an average of $28 \%$, rising to over $\$ 1$ thousand million in 2010 from $\$ 822$ million in 2009. The industry has also continued to expand in terms of the number of institutions. According to the latest figures, the number of Shariah-compliant institutions has reached to 435 , with a further 191 conventional banks having Shariah divisions. Moreover, the Islamic banking geographies are stretching beyond the existing strongholds of a few countries in the Middle East and have now reached to Europe, North America, Asia and Africa. Muslims account for about $27 \%$ of the world population, being Islam the fastest growing religion in the world; there is a high potential market increasingly searching for financial instruments that adhere to their principles. Some non-Muslims are also participating in Islamic banking because they consider it to be commercially sound (Brooks 1999).

When an activity (financial services, for example) is growing in size and complexity as formal institutional change (create new one or adapted old ones) is needed (regulation, supervisory boards, valuation methods, accounting principles) both at a national international levels that comprise the countries that follow the same economic and financial model. The Islamic countries co-evolve, changing institutions or creating new ones, both at local or international institutions. The process of institutional change is open and partially or totally unpredictable about how organizations and institutions can evolve.

The paper is structured as follows. In section two we consider the fundamentals of Islamic financial services industry and the need or demand for institutional changes. Next we offer an overview of the development of Islamic banking and the creation or adaptation of institutions. In section five we introduce the Islamic financial products, both traditional and new instruments created more recently. In the following section the comparison between traditional and Islamic banking is made, which allow us to consider the effect of the current financial crisis in the Islamic institutions. Finally we offer the main conclusions derived from the paper.

\section{Fundamentals of Islamic Banking and Demand for Institutional Changes}

Each Islamic Financial firm has its own Shariah board which is responsible of prevailing local and legal tradition over all financial products and provides interpretations that, combined with the market's competitive pressure, shape the activity of each organization. The Shariah board signs the fatwa(Note 2), a religious opinion on Islamic law issued by an Islamic scholar. There are several fatwa in Islamic finance issued through Shariah board, individually or through collective ijtihad and fatwa.

An important principle behind Islamic finance is the desire to maintain the moral purity of all transactions. The funds intended for Shariah-compatible investments should therefore not be mixed with those of non-Islamic investments. This requirement is not based on the assumption that the activities of non-Muslims are intrinsically impure. The rationale behind this principle is rather one of prudence, in the sense of taking all the necessary precautions to ensure that Islamic funds do not become mixed with other funds that may be involved with riba (prohibition of interest), gharar (prohibition of carrying out doubtful contracts with uncertain results) or haram (illegal) activities.

While Islamic banks respond to the needs of Muslim customers, they are not acting in fact as religious institutions, although they have an important role in Muslim societies. Like other banks they are profit-maximizing entities. They act as intermediaries between savers and investors and offer custodial and other services found in traditional banking systems. The constraints facing Islamic banks are, however, different. As we said before, they are based on prescriptions in Shariah law, which encompasses a set of duties that also apply to commercial transactions, and the hadith -the authentic traditions-. Islamic law affects how the banking 
system functions. Four factors in particular are unique to Islamic banking. We summarize them as follows (for further details, see El-Gamal (2006)):

- Prohibition of interest (Riba): Riba is the major difference between Islamic and traditional banking. Islam prohibits all forms of riba (interest paid on loans) on the grounds that interest rates are a form of exploitation, inconsistent with the notion of fairness. Practically, this implies that Shariah law does not allow fixing in advance a positive return on a loan as a reward for waiting under the argument is that riba implies an improper appropriation of other people's property and is bad for development. Islam does recognize the importance of the time value of money, but the time value is not realized as part of a loan contract; it can be realized only as part of a real transaction.

- Prohibition of maysir (games of chance, gambling) and of gharar (chance): Islamic banking bans speculation, which is increasing one's wealth by chance rather than productive effort. While entrepreneurship itself could be interpreted as a form of gambling maysir refers to unnecessary uncertainties not part of everyday life. It is similar to asymmetric information: the objective is to minimize possibilities of misunderstanding and conflicts between contracting parties.

- Prohibition of haram (illegal) activities: The code of conduct for Islamic banks allows them to finance only halal (legal) activities. They are not supposed to lend to companies or individuals involved in haram industries: prohibited industries such as those related to pork products, pornography or alcoholic beverages.

- Payment of part of bank profits to benefit society (zakat): Muslims believe that justice and equality in opportunity (no outcome) are crucial for a society to function. One mechanism to achieve this goal is to redistribute income to provide a minimum standard of living for the poor people. This form of giving, zakat, is also one of the five tenets of Islam. Zakat represents around 2'5\%-3\% of net income.

Also as part of their mission Islamic banks are encouraged to make social benevolent loans (charitable loans, Qard Hassan) to individuals or organizations. These loans do not carry an interest charge or mark-up. Banks are allowed to charge the borrower a service fee to cover administrative expenses (the fee is not related to the amount or maturity of the loan. However these loans are not very common in most Islamic countries (Zaher and Hassan, 2001).

Considering the characteristics mentioned above, Islamic banks expected to undertake such an important social function. For most of the people, Islamic banks fill two very important positions in the community: religious and financial. On the religious side, Islamic banks take responsibility for complying with the Islamic law, thus setting an example for people in the community who observe their activities. On the financial side, the banks' control of large funds and revenues helps them to undertake a social role. Under the principles of Islamic world the model of non-optimization is crucial (Nelson and Winter, 1982) being applicable the objective of satisfactory results in a world of limited rationality (Simon, 1957).

The important transformation followed by an increasing complexity of the economic and financial activities in the Islamic World has been co-evolved with institutional changes needed to try to deal with the new realities faced. The rise of economic interdependence and radical environmental changes brings institutional adaptation as a response to complex forms of uncertainty (North, 2005). Institutions are patterns of human interaction as well as modes of coordination of human (economic, social and political) activity (Nelson and Sampat, 2001). Institutions can be of two types (Nelson, 1990): formal rules (constitutions, laws, regulations, international agreements) and informal modes (principles, norms of behavior, values, and self-imposed codes of conduct). Institutional change is produced by modification in the character and content of either or both types of institutions. The process of institutional change is open and partially or totally unpredictable where organizations and institutions can evolve. As a matter of fact we can think of the economic and financial crisis in the global economy (especially in the western developed world) as well as in the Islamic world in the last three decades. As we will underlying later in the Islamic perspective there is a domain of informal institutions that has been incorporated new formal institutions, which varies among countries (we can mentioned Malaysia and Libya, as an example).). There is a lack of uniformity in the religious principles applied in Islamic countries since there are differences in the interpretation of such principles by the corresponding schools of thought. Also there are differences in supervisory regimes in Muslim countries (Zaher and Hassan, 2001). As well as difficulties in operating in non-Islamic countries owing to the absence of a regulatory organization that operates in accordance with Islamic principles.

Islamic countries in general became a relevant part of a non-ergodic world of continuous change since it is not possible to forecast the future basically based on the past (Cantwell, et al, 2010). However, a tendency towards a more uniform regulatory and legal framework has been observed and it could be expected to evolve new 
institutions and adaptations of some national ones to fulfill the demands of a more complex and relevant economic and financial system of the Islamic world. The relevance of non-ergodic uncertainty in the Islamic world relies on the genuine unpredictability from past structures and trends. The widening of complex interconnections among members countries and with the rest of the world (governments, MNEs, domestic firms and civil society) feeds the relevance of non-ergodic uncertainty that relies on the genuine uncertainty from past structures and trends. The international financial and economic crisis, the growth and differences in economic structures, as well as the "Arab spring" and the expectations created are factors that contribute to a non-ergodic uncertainty. To face with this type of uncertainty requires continuous adaptation and creation of new institutions. Effective institutional changes accepted by the society (the people) will contribute to the formation of expectations of improving and hence to economic growth.

The perspective of national economic systems is static and top-down in their orientation (Casson and Lundan, 1999; Jackson and Deeg, 2008) but the development of size and complexity of value chains and the formal institutional changes generated can affect significantly to the previous design of the national system. The interaction between market and non-market agents plays a key role in Islamic societies. Within this context it is understandable that any institutional system reached by a given country or economic model is never optima since in fact it represent adaptations to relevant specific circumstances of both domestic or local and international environments.

When an activity (financial services, for example) is growing in size and complexity formal institutions are needed (create new forms or adaptive old ones); regulation, supervisory boards, valuation methods, accounting principles. The Islamic countries co-evolve, changing institutions or creating new ones, both with local and international institutions that comprise the countries that follow the same economic and financial model. As an example, we know that the principal means of Islamic finance are based on trading (on a commercial transaction we could say) and it is essential that there is a risk involved in any trading activity. According to the Islamic principles any gains relating to trading are shared between the person providing the capital and the person providing the expertise. To deal with risk the Islamic finance has used the concept of mutuality and has signed agreements with MIGA from the World Bank Group.

\section{History and Growth of Islamic Banking and Financial Institutions}

The first generation of Islamic banks was developed in Egypt and Malaysia in the 1960s, although the Egyptian experiment did not last very long, and it was not until the mid 1970s when it started to take hold in many Muslim countries (Karbhari et al, 2004). The 1970s saw two oil-price shocks, which led to a massive transfer of wealth from the oil-consuming to the oil-producing countries. This situation led to seek an alternative to traditional banking that was consistent with Islamic believes. The second oil shock coincided with the Iranian revolution, and the first Islamic republic that spread the Islamic teaching to other countries and paved the way for more Islamic financial institutions.

The creation of the Islamic Development Bank (IDB) in 1975 in Jeddah gave impetus to the diffusion of Islamic Banking by centralizing expertise. In its infancy, implementation of Islamic banking required an interpretation of the Shariah law. The demand for Islamic banking led Islamic scholars to address this problem. In the first few years, basic implementation tools were created and widely accepted to help the development of Islamic Finance. In 1974 the Union of Arab Banks was founded, followed in 1975 by the Islamic Development Bank and with some parallelism with the IMF in 1976 was founded The Arab Monetary Fund. Later on in 2002, among other recent institutional developments that have helped Islamic banking diffusion, was established the Islamic Financial Service Board (IFSB) with a mandate to set prudential standards for Islamic banks.

During its first three decades, Islamic finance focused on two core markets: Bahrain in the Middle East and Malaysia in South-East Asia. The two countries became pioneers, establishing the two leading financial centers for Islamic banking. By the early 1980s, Malaysia took the lead in the Islamic world thanks to official support that considered Islamic banking a pillar of development. The government was crucial to the establishment in 1983 of the country's first Islamic bank, the Bank Islam Malaysia Berhad. Similarly, Bahrain has pursued Islamic finance as a niche that could allow it to build on its strong banking sector and become a major financial center. Malaysia and Bahrain have allowed a mixed (dual) financial system to coexist for a long period of time. Since 1994 has been operating the Malaysian Interbank Islamic Money Market, with several Islamic instruments and in 2002 in a similar vein the Bahrain Monetary Authority established the Liquidity Management Center

Islamic banking has established itself as an emerging alternative to conventional interest-based banking and is expanding rapidly over the last two decades in both Muslim and non-Muslim countries. In the past two decades, Islamic banks have recorded high growth rates both in size and number around the world. Islamic banks operate 
more than seventy five countries, most of them in the Middle East and Asia although they are starting to grow up in Africa (Moodys, 2008), United States and Europe. A growing number of western companies are offering Islamic investment products to interested Islamic investors worldwide. In some countries (Iran, Pakistan and Sudan), the entire banking system has been converted to Islamic banking, while other countries are still dominated by conventional banking institutions operating alongside Islamic banks.

Iran has taken steps to move their entire banking system toward Islamic finance, disallowing interest payments (Iwbal and Mirakhor, 1987). In any case, it is out of doubt that the expansion of Islamic banking has in the past few years accelerated, with the industry diversifying out of traditional territories into countries with large Islamic populations such as the United Kingdom. Africa in particular, with a Muslim population of more than 400 million, has seen an expansion in recent years (Moody's, 2008).

The United States had a developed banking system that attracted overseas investors, including those oil-rich wealthy Muslims. However, the conflict between the United States and Middle-East was crucial in 2001 following terrorist attacks in September 2001 led to many Muslims closing their US banking services and seeking new places to deposit their money (Taylor 2007). The United Kingdom (UK) was the first country to publicly declare its intent to adopt and push Islamic finance (Malik, et al 2011). The UK is home of about two million Muslims plus about half a million of regular visitors and Muslim population in UK has increased ten times faster than rest of the society (Office of National Statistics, 2010). This makes a sizeable market to cater for and UK Government is committed to provide its citizens freedom in the way they live and conduct their commercial activities as long as they are not violating the laws of the country(Note 6). In general a question may be raised of whether Islamic institutions require special supervision and regulatory provisions in western countries where Islamic banks operate

The exact size of the Islamic banking sector is difficult to be estimated. Pakistan for example, defines all of its financial institutions as Islamic even though western bankers say that many of the transactions are still effectively conventional banking. Saudi Arabia, on the other hand, does not formally admit the distinction between conventional and Islamic banking. Many Islamic banks are among the largest banks in their respective countries (Ray 1999). Over the last two decades, Islamic Banking and Finance has grown into a full fledge system and is growing at a rate of $15 \%$ to $20 \%$, which means it is doubling every 5 years. The number of Islamic Banks increased from 22 in 2001 to 190 in 2011 (se Annex 1)

It can be witnessed by the fact that there are over 475 Islamic Financial Institutions in over 75 countries around the world. It means a very high growth rate of 47\% (World Takaful Report 2010 - Ernest \& Young). Global Islamic Banking and Finance Industry was worth US $\$ 822$ billion by the end of year 2009 which is expected to grow to US \$1.00 trillion in assets by the end of 2010 (The Islamic Fund \& Investment Report 2010 - Ernest \& Young).

Table 1. Islamic banks financial highlights 2009 (Thousands US Dollar)

\begin{tabular}{lccccc}
\hline Region & Total Assets & Total Deposits & Total Liabilities & $\begin{array}{c}\text { Total } \\
\text { Income }\end{array}$ & $\begin{array}{c}\text { Net Profit for } \\
\text { The Year }\end{array}$ \\
\hline Europe & 1.925 .388 & 348.025 & 1.238 .047 & 62.042 & -94.439 \\
Middle East & 217.835 .725 & 145.036 .712 & 177.464 .256 & 10.664 .435 & 2.085 .940 \\
Asia & 202.978 .236 & 155.513 .954 & 185.401 .657 & 8.677 .643 & 1.848 .200 \\
Africa & 113.752 .092 & 61.805 .678 & 87.557 .946 & 10.998 .912 & 6.711 .715 \\
& & & & & \\
TOTAL & & & & & \\
\hline
\end{tabular}


Table 2. Main political events and financial institutions development in the Islamic model

\begin{tabular}{|c|c|c|}
\hline DECADE & EVENTS & CHARACTERISTICS. EFFECTS. CHANGES \\
\hline \multirow[t]{3}{*}{40 's } & State of Israel & - Beginning of the State of Israel \\
\hline & Starting of Islamic & - Islamic countries start to be independent \\
\hline & Countries' Independence & \\
\hline \multirow{3}{*}{$\begin{array}{l}50 \text { 's and } \\
60 \text { 's }\end{array}$} & Most of Islamic Countries' & - Most of Islamic countries became independents in years 50's and 60's. \\
\hline & Independence & In Most of the cases the colonizers were UK and France. \\
\hline & $\begin{array}{l}\text { First Islamic banking } \\
\text { attempt }\end{array}$ & $\begin{array}{l}\text { - Egypt and Malaysia started the first generation of Islamic investments } \\
\text { but the experiment did not last very long }\end{array}$ \\
\hline \multirow[t]{5}{*}{70 's } & Oil Crisis 1973-1979 & - World Oil Crisis. Radical increase of capital in OPEC \\
\hline & Islamic Banking Starts & members. \\
\hline & Establishment of first & - Islamic Banking starts to take hold in Dubai, being \\
\hline & financial institutions & followed by many others Islamic countries. \\
\hline & & $\begin{array}{l}\text { Born The Union of Arab Banks (1974), The Islamic } \\
\text { Development Bank (1975) and The Arab Monetary Fund } \\
\text { (1976) }\end{array}$ \\
\hline \multirow[t]{5}{*}{80 ’s } & & - Intensification in the conflict between Israel and Palestine \\
\hline & Islamic Banking & - $\quad$ 1983. Establishment the country's first Islamic Bank in Malaysia \\
\hline & development & - $\quad$ Born the Islamic Research and Training Institute (1981), The Gulf Cooperation \\
\hline & Growth of Islamic & Council (1981) and The International Association of Islamic Economics (1984) \\
\hline & Financial Institutions $¿ ?$ & \\
\hline \multirow[t]{8}{*}{90 's } & Invasion of Kuwait & $\begin{array}{l}\text { - 1990. The Invasion of Kuwait and annexation by Iraq. Authorized by } \\
\text { the UN an American-led coalition of } 34 \text { nations fought the First Persian }\end{array}$ \\
\hline & New Islamic Financial & Gulf War to reinstate the Kuwaiti Emir \\
\hline & Institutions & - Born The Institute of Islamic Banking and Insurance (1990), The \\
\hline & & Accounting and Auditing Organisation for Islamic Financial \\
\hline & & Institutions (1991), the Islamic Corporation for Insurance of \\
\hline & Launch of First Islamic & Investments and Export Credits (1994) and the Islamic Corporation for \\
\hline & Index & the Development of the Private Sector \\
\hline & & - The Dow Jones Islamic Index is launched. \\
\hline 00 's & September 11 Attacks & $\begin{array}{l}\text { - 2001. World focus on Islamic terrorist. Transfer of capital from USA to } \\
\text { Islamic countries and other sites (UK). Increase of terrorism and } \\
\text { cultural "Islamic Identity" }\end{array}$ \\
\hline
\end{tabular}

Invasion of Afghanistan Invasion of Iraq

Arab Spring

Development of new financial institutions
2003. considered a continuation of the Gulf War of 1991, prior to which Saddam Hussein had invaded Kuwait

- 2010-2011 Revolutionary wave of demonstrations and protests occurring in the Arab world. Since 18 December 2010 there have been revolutions in Tunisia and Egypt a civil war in Libya resulting in the fall of its regime; civil uprisings in Bahrain, Syria, and Yemen; major protests in Israel, Algeria,Iraq, ${ }^{[}$Jordan, Morocco, and Oman, and minor protests in Kuwait, Lebanon, Mauritania, Saudi Arabia, Sudan, and Western Sahara. Increase of country risk and expectation of both democracy and religious and politic fundamentalism.

- The General Council for Islamic Banks and Financial Institutions (2001), The International Islamic Financial Market (2002) and the Islamic Financial Services Board (2002) 


\section{Main Islamic Financing Products and Institutions}

The traditional instruments of Islamic banking and finance are basically easy to understand and can be compared to a similar one existing Western financial activity. These types of contracts and its main characteristics are as describe as follows.

Islamic banks can only accept fiduciary deposits, for which they cannot pay interest, since interest would be considered usury/riba once the principal is guaranteed. On the other hand, they are allowed to accept Fixed Income Security such as "investment account" funds, which may invest on behalf of the account holders, and share profits and losses thereof. This may give gives rise to a moral hazard problem, and the need to a regulatory issue regarding protection of investment account holders who are neither protected as creditors (first claimants), nor as stock-holders with representation on boards of directors. Attempts by significant juristic bodies to justify interest-bearing bank deposits have been strongly rejected by most Islamic jurists, especially the ones to whom Islamic bank customers look for guidance. (El Gamal, 2006)

Murabaha: basically it is a cost-plus profit financing transaction in which a tangible asset is purchased by an Islamic institution at the request of its customer from a supplier. One of the main characteristics is that the contract must include disclosure of cost to the buyer. The Islamic institution then sells the asset to its customer on a deferred sale basis with a mark-up reflecting the institution's profit. If the profit is considered excessive by the Shariah Board, the bank has to return a portion of the profit to the client. The customer takes the responsibility of negotiating all the key commercial terms with the seller of the asset. The mark-up on the asset cannot be altered during the life of the contract. The Murabaha deals offer enough flexibility to be used in real estate and project financing, but historically it has been used primarily for trade finance (Usmani 2008). This instrument accounts for more than $77 \%$ of the total Islamic modes of finance in 2009 (more than $88 \%$ in Middle East and more than $76 \%$ in Asia)(see table 3). Advocates of Islamic banking argue that the profit mark-up of Murabaha financing is not considered as "interest" because profit is made on the Exchange of Money for goods and not Money for Money. To be Shariah-compliant, the bank must enter into separate contracts with the supplier and the customer, take physical possession of the goods, and de-link the mark-up from the period of repayment (Mills and Presley, 1999)

As Islamic banks are not permitted to hold liquid assets like treasury bills, due to riba, banks in London such as the Bank of London, started accepting deposits on a basis that there would be a mark up as a result of a Murabaha transaction, with a short term trade being the transaction on the London Metal Exchange. Consequently as a result non-Muslim British bankers soon became experts in Shariah principles learning innovative and imaginative methods of responding to Muslim client's request (Oakley, 2009). The creation in 2004 of Islamic Bank of Britain, being the first Islamic institution in the world to offer Murabaha treasury deposit accounts, proved that dynamic economies have innovative financial sectors.

Ijara and Ijara Wa-Iqtina: An Ijara and Ijara wa-Iquina are Islamic leasing concepts similar to western operating and finance leases. Ijara is similar to a conventional operating lease, where in an Islamic bank (lessor) leases the asset to a client (lessee) for agreed on lease payments for a specified period of time, but with no option of ownership for the lessee. The maintenance and insurance of the leased asset is the lessor's responsibility. On the other hand, Ijara wa-Iqtina is comparable to the Western financial or capital lease, where the lessee has the option of owning the asset at the termination of the lease. In this case, the bank (lessor) purchases the asset such as a real state, machinery and equipment or even an entire project and lesses it to the clients for an agreed on lease rental, together with client agreement to make lease payments towards the purchase of the asset from the lessor. The conditions governing both types of leasing are that assets must have a long/secure productive life, and must not be handled in a non-halal way. Leasing in Islamic banking explains about $15 \%$ of the total Islamic finance in 2009 but near $35 \%$ in Europe (see table 3).

Istisna'a or Istinsa: it is a pre-delivery financing and leasing structured mode that is used mostly to finance long-term large-scale facilities involving, for example, the construction of a power plant. So, this tool of financing is useful for infrastructure projects. The Islamic institution could either own the plant, charge the lessee (project company) a fee based on profits, or sell the plant to the project company on a deferred basis with a profit mark-up similar to a Murabaha transaction. Unlike a Murabaha transaction, however, certain expenses that cannot easily be reflected in a sale and purchase agreement can be included in the fees to be paid to the Islamic institution by the project company. This type of financing, that in some way complements the Ijara type, accounts for nearly $2 \%$, mostly in Middle East (see table 3).

Mudaraba: it is a type of partnership whereby skill and money brought together to conduct business. Profit is shared according to agreement while loss is born by capital provider only. Under this scheme Islamic Finance 
Institutions provide capital to financially weak but skilful people to do the business and share outcome with the Financial Institution. Mudaraba agreement is similar to Western-style limited partnership, with one party contributing capital while the other runs the business, and profit is distributed based on a negotiated percentage of ownership. In case of a loss, the bank earns no return or a negative return on its investment and the agent receives no compensation for his effort. In 2009 Mudaraba financing was 5,5\% of the total but it accounts for more than 33\% in Islamic Finance in Africa (see table 3).

Musharaka: it is similar to a joint venture, whereby two parties (an Islamic Financial Institution and a client) provide capital for a project which both may manage. Profits are share in pre-agreed ratios but losses are borne in proportion to equity participation. It conforms to the principle of profit and loss sharing and it is suitable for long-term project financing; hence it is considered to be the purest form of Islamic finance. Most theoretical models of Islamic banking are based on the Mudaraba and or /Musharaka concepts of profit and lost sharing (PLS) (Dar and Presley, 2000). Musharakah represents around 6\% of the total financing, 18\% in Africa and 2.3 in Europe (see table 3).

Bai-Salam and Bai Muajjal: These two instruments are used in futures trading. Bai Muajjal literal meaning is deferred/credit sales. Islamic financial Institutions are using this mode for finance the customer's needs by supply of desired commodities. Under Bai Muajjal cost may or may not be disclosed. In a Bai Salam contract the buyer pays an agreed on price in advance for commodities that will be delivered at a future date (in fact forward or future contract). In both cases the fixed price can be the same or higher or lower as the spot price. The available data (table 3 ) shows a very low proportion $(0.02 \%)$ of total financing through forward or future contracts.

Table 3. Traditional contracts: Islamic modes of finance

\begin{tabular}{|c|c|c|c|c|c|c|c|c|c|c|c|c|c|c|}
\hline \multicolumn{15}{|c|}{ 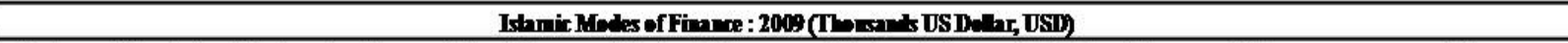 } \\
\hline \multirow[t]{2}{*}{ Region } & \multicolumn{2}{|c|}{$\begin{array}{c}\text { Miraluah \& Deforred } \\
\text { Sales }\end{array}$} & \multicolumn{2}{|c|}{$\begin{array}{c}\text { Ijpra avdljara Wh- } \\
\text { Iqtion }\end{array}$} & \multicolumn{2}{|c|}{ Mrhrabah } & \multicolumn{2}{|c|}{ Mnshrakah } & \multicolumn{2}{|c|}{$\begin{array}{c}\text { BaiSabnakai } \\
\text { Mmajel }\end{array}$} & \multicolumn{2}{|c|}{ Istisen } & \multicolumn{2}{|c|}{ Other } \\
\hline & $*$ & Valne & $*$ & Valne & $*$ & Value & $*$ & Valne & $*$ & Valne & $*$ & Value & $*$ & Valese \\
\hline Ewrepe & $43,19 \%$ & 356.590 & $34,73 \%$ & 286.687 & $0,84 \%$ & 6.929 & $2,32 \%$ & 19.183 & NA & NA & NA & NA & $25,60 \%$ & 211.385 \\
\hline $\begin{array}{l}\text { MFine } \\
\text { Fast }\end{array}$ & $88,05 \%$ & 106.737 .615 & $18,83 \%$ & 22.826 .547 & $3,00 \%$ & 3.631 .152 & $3,01 \%$ & 3.654 .100 & NA & NA & $3.79 \%$ & $4,597,903$ & $2,32 \%$ & 2.814 .486 \\
\hline Asin & $76,42 \%$ & 97.225 .974 & $10,92 \%$ & 13.892992 & $2,26 \%$ & 2880225 & $6,60 \%$ & 8.393 .824 & $0.04 \%$ & 49,665 & $0.45 \%$ & 566,790 & $7,53 \%$ & 9.582 .649 \\
\hline Afrina & $31,63 \%$ & 8.125 .093 & $16,83 \%$ & 4.325 .081 & $33,55 \%$ & 8.620572 & $17,83 \%$ & 4.580 .883 & $0.03 \%$ & 7,618 & $0.01 \%$ & 3,687 & $4,49 \%$ & 1.153914 \\
\hline & $77,26 \%$ & $212.45,272$ & $15,03 \%$ & 41331_307 & $5,51 \%$ & 15.138 .57 & $6,05 \%$ & 16.647990 & $0,02 \%$ & 57.283 & $1,85 \%$ & 5.163380 & $5,01 \%$ & 13.762444 \\
\hline
\end{tabular}

As the growth and needs of the Islamic economy become bigger and complex new development of financial instruments and institutions were needed (see tables 2 and 3). To deal with insurance of risks, to obtain long term financing and to design more efficient mechanisms adaptation and creation of institutions were made. To this aim we have to mention The Islamic Research and Training Institute (founded in 1981), the International Association of Islamic Economics (IAIE) in 1984, the Institute of Islamic Banking and Insurance (founded in 1990), the Accounting and Auditing Organization for Islamic Financial Institutions (AAOIFI), in1991, and the Islamic Corporation for the Development of the Private Sector (1999).

New institutions that help the development of new products were the General Council for Islamic Banks and Financial Institutions (founded in 2001) and the International Islamic Financial Market (created in 2002). The Islamic Financial Services Board (IFSB) (founded in 2002) was created to satisfy the need for a set of internationally accepted regulations. In this regard in 2005 IFSB issued two regulatory standards on capital adequacy and risk management for Islamic institutions; issues in parallel with the Basel II Accord (Solé, 2008).

Thus the creation of different international Islamic institutions gave impetus to the diffusion, harmonization and growth of Islamic Banking as well as towards an effective integration of the Islamic system and with the western model, not only within countries that have adopted both systems but also among nations that only use one system. In this respect we can classify institutions in three categories: Cooperation and development ( Union of Arab Banks,1974; Islamic Development Bank, 1975; Arab Monetary Fund, 1976); Norms and principles (Islamic Research and Training Institute, 1981; International Association of Islamic Economics, 1984; Institute of Islamic Banking and Insurance, 1990; Accounting and Auditing Organization for Islamic Financial Institutions, 1991; Multilateral organizations (Islamic Corporation for Insurance of Investments and Export Credits, 1994; Islamic 
Corporation for the Development of the Private Sector; General Council for Islamic Banks and Financial Institutions, 2001; International Islamic Financial Market, 2002; Islamic Financial Standard Board 2002).

Within this institutional environment, new products have been developed by the modern Islamic Banks, being the most important sukuk and takaful.

Sukuk is a financial certificate that represents ownership in an asset. It grants the investors a share of the asset along with profit and risk resulting from such ownership. Sukuk can be structured based on the principles of a contract of exchange (e.g. ijara, murabaha or istisna'a) and contract of participation (mudaraba or muyasaka). The primary condition for the issuance of sukuk is the existence of assets on the balance sheet of the government, the monetary authority, the corporate body, the banking and financial institution, or any entity that wants to mobilize their financial resources. Sukuk are emerging as a very important vehicle for resource mobilization. However, we have to take into consideration at least two important characteristics when we talk about sukuk:

Sukuk is a difficult instrument to structure as it requires costly legal, religious advice and operating procedures (different skills and resources) to make it work (Elwaleed, M.A.). It is a resources-intensive process that involves the conduct of market research, product development and analytical modeling (Askari, H. et al. 2009). In general Islamic financial institutions are generally of small size and may not have the necessary budget for research and development (Standard\&Poors, 2009). Although sukuk can be negotiated and traded freely in the market, it remains active merely at the primary market. Most holders keep sukuk to maturity and many of the certificates are held by large institutions. Besides that in general the minimum investment requirements of the sukuk issues are often very large. Consequently, it is unavailable for the average private investors.

The most active country in the issue of sovereign sukuk is Bahrain; it is the only one that made issuance every year, followed by UAE and Malaysia (see table 4). On the other hand issuance of corporate Sukuk re lead by Malaysia (every year issue the asset in a considerable amount), further behind are UAE and Saudi Arabia (see table 5).

Table 4. Total global sovereign sukuk issuance

\begin{tabular}{lccccccccc}
\hline Year & $\mathbf{2 0 0 1}$ & $\mathbf{2 0 0 2}$ & $\mathbf{2 0 0 3}$ & $\mathbf{2 0 0 4}$ & $\mathbf{2 0 0 5}$ & $\mathbf{2 0 0 6}$ & $\mathbf{2 0 0 7}$ & $\mathbf{2 0 0 8}$ & US\$ Millions \\
\hline & & & & & & & & & \\
Bahrain & 100 & 200 & 480 & 356 & 107 & 798 & 617 & 467 & 3125 \\
Saudi Arabia & & & & & & & 1.333 & & 1333 \\
Qatar & & & 700 & & & & & & 700 \\
UAE & & & & 1.000 & & 3.520 & 3.425 & 1.731 & 9676 \\
Pakistan & & & & & 600 & 133 & 339 & & 1072 \\
Malaysia & 150 & 600 & & & & 1.315 & 3.777 & & 5842 \\
Indonesia & & & & 8 & & & 81 & 62 & 151 \\
Brunei & & & & & & 380 & 222 & & 602 \\
Germany & & & & 123 & & & & & 123 \\
& & & & & & & & & \\
Total Issued & 250 & 800 & 1180 & 1487 & 707 & 6146 & 9794 & 2260 & 22624 \\
\hline
\end{tabular}

Enhancing Capital Markets Cooperation among IDB Member Countries (IDB, 2009) 
Table 5. Total global corporate sukuk issuance

\begin{tabular}{|c|c|c|c|c|c|c|c|c|c|}
\hline Year & 2001 & 2002 & 2003 & 2004 & 2005 & 2006 & 2007 & 2008 & US\$ Millions \\
\hline Bahrain & 98 & & & & 584 & & & 400 & 1082 \\
\hline Kuwait & & & & & 200 & 1.010 & 993 & & 2203 \\
\hline Saudi Arabia & & & 400 & 417 & 500 & 818 & 4.350 & 67 & 6552 \\
\hline Qatar & & & & & & 270 & 438 & 163 & 871 \\
\hline UAE & & & & 165 & 950 & 4.775 & 7.292 & & 13182 \\
\hline Pakistan & & 6 & & & & 47 & 725 & 32 & 810 \\
\hline Malaysia & 530 & 160 & 4.072 & 4.949 & 8.747 & 13.733 & 22.752 & 2.480 & 57423 \\
\hline Indonesia & & 19 & 65 & 93 & 59 & & 113 & & 349 \\
\hline Brunei & & & & & & 200 & & & 200 \\
\hline USA & & & & & & 166 & & & 166 \\
\hline Sudan & & & & & & & 130 & & 130 \\
\hline \multicolumn{10}{|l|}{ Cayman } \\
\hline Islands & & & & & & & 100 & & 100 \\
\hline & & & & & & & & & 0 \\
\hline Total Issued & 628 & 185 & 4537 & 5624 & 11040 & 21019 & 36893 & 3142 & 83068 \\
\hline
\end{tabular}

Enhancing Capital Markets Cooperation among IDB Member Countries (IDB, 2009)

It could be seen that while sovereign issues showed no significant growth, growth resulted from international corporate issues which have been growing annually at about 150 per cent up to 2005 , peaking at $400+$ per cent as at December 2006.

The insurance business itself is prohibited under the Islamic principles. This prohibition is based on two considerations: the first consideration is that "safety" or insurance" is not itself viewed as an object of sale in classical Islamic jurisprudence. The argument is that the insured-insurer relationship is viewed to be one akin to gambling, wherein the insured as buyer pays periodic premium as price, but may or may not receive the object of sale (compensation in case of loss), depending on chance. The second consideration that prompted Islamic jurists to forbid insurance is the fact that insurance companies tend to concentrate their assets in interest-based instruments such as government bonds and mortgage-backed securities. The alternative proposed is marketed under the Arabic name Takaful, which has recently begun making inroads in Islamic countries, after years of slow growth (see figure 1). Islamic Takaful Industry was worth US $\$ 5.3$ billion by the end of year 2008, which is expected grow up to US $\$ 10$ billion by the end of the year 2012 (Iqbal \& Molyneux, 2005).

The main idea behind Takaful is similar to mutual insurance, wherein there is no commutative financial contract that allows one to interpret premium payments as prices and insurance claim fulfillment as an object of sale. Rather, policy holders are viewed as contributors to a pool of money, which they agree voluntarily to share in cases of loss to any of them. Early Takaful companies were in fact structured as stock insurance companies, but the language of "voluntary contribution" to insurance claimants was used to argue that the contract was not a commutative one. Inroads have recently been made by Bank Al-Jazira of Saudi Arabia by modifying its insurance to better approximate western-style mutual insurance, and the model appears to be boosting its underwriting success. Regardless of structure, both types of Takaful companies do not invest in conventional government bonds and fixed income securities. Islamized analogues of those securities have become increasingly available in recent years, further contributing to the industry's growth. Despite the industry's growth, it has not yet reached a critical size that would support the equivalent of re-insurance, or "re- Takaful", companies to emerge. Consequently, Islamic jurists have invoked the rule of necessity to allow Takaful companies to sell their risks to conventional re-insurance companies, with the provision that they should work to 
develop a re- Takaful company as soon as possible

Also it is expected that besides the development of an Islamized re- insurance (re-Takaful) Islamic insurance companies are likely to be deeper developed alongside Islamic banks. As it has been the case in conventional banking, Islamic banks may start promoting their own takaful products or own takaful companies.

Given the relevance of foreign trade and to a certain extends the international investment (intraregional first and with third countries also) in 1994 was created the Islamic Corporation for the Insurance of Investment and Export Credit (ICIEC), established by the Islamic Development Bank (a multilateral development bank), with 35 member countries (members of The Organization of the Islamic Conference) spanning North and East Africa, the Middle East and Central and South-East Asia. ICIEC has been increasing its partnership with MIGA (Multilateral Insurance Guaranty Agreement of the World Bank) and COFACE...The objective is to provide of Shariah compatible export credit and investment insurance and reinsurance with the aim of increasing trade and foreign direct investment for its members countries. The risk covered by this institution is: transfer and convertibility of foreign currency, expropriation, war and civil disturbance and breach of contract.

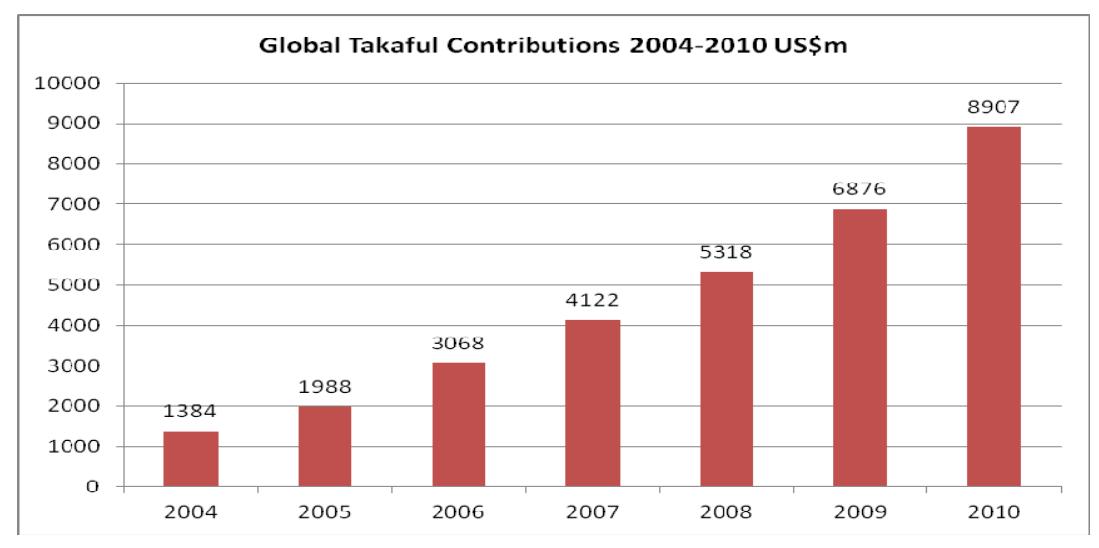

Figure 1. Takaful contributions

Source: The world takaful report (Ernst\&Young, 2010) and author's research

Many Muslim countries or with majority of Muslim population (Turkey, Dubai) have well established stock markets. Several of these markets are attempting to apply Islamic principles of trading; being Malaysia perhaps the most advanced one. The main problem of these markets is the creation of excessive uncertain (Gharar) and the issue of Qimar (gambling products), that is, the speculation in the stock market, buying and selling stocks solely for the short-term gains resulting from uncertainty in the market. Also it is not allowed that one party to a trade imposes a contract to an unwilling party or imposes conditions not acceptable to the other party (Ikrah). Also traditional Western preferred stocks are not acceptable, since there is a fixed return to the investor. There is lack of studies focusing on the cost of equity capital in Islamic capital markets. We have some recent evidence focusing on the Sudan telecommunications company that is listed on the Khartoum (Sudan) market as well as on the Arabian Gulf Stock exchange, suggesting that fully Sharia compliant stock markets are segmented between them as well as from global capital markets (Hearn et al., 2012).

Traditional Western preferred stocks are not acceptable, since there is a fixed return to the investor. As we mentioned above investments in equity of companies that produce products that are forbidden to Muslims (e.g., beer, pork products, etc.), as well as some others that Islamic jurists decided to forbid (e.g., weapons producers, cutting-edge genetic research, etc.) is not allowed. Besides that to deal with the theme of interest in the real life is difficult since most companies either have excess liquidity, in which case the efficient management of the situation means earn interest, or if they decide to use leverage they will have to pay interest. To deal with these situations Islamic jurists decided to invoke the rule of necessity (the universe of equity securities to choose from would be too small if they exclude all companies that either pay or receive interest). To overcome the difficulties of functioning just mentioned the Islamic jurist decided to impose three financial scenarios: i) exclude companies for which accounts receivables constituted a major share of their assets; ii) exclude companies that had too much debt; and iii) exclude companies that received too much interest. Based on these screens the Dow Jones Islamic index(Note 7) set the following rules that became generally accepted, excluding 
with receivables accounted for more than $45 \%$ of assets; and with a debt ratio to average of market capitalization exceeds $33 \%$ or with interest income exceeds $5 \%$ (or, for some, $10 \%$ ) of total income.

Mutual fund companies either mimic the above screening rules, or obtain licenses from one of the indices, which they use as a benchmark. Growing unanimity over the general screens used by Islamic mutual funds has enabled Islamic private equity and investment banking boutiques to thrive. Those institutions typically collect investor funds in Gulf Cooperation Council countries (investors from Saudi Arabia, Kuwait, and U.A.E. being primary sources of funds). Through local subsidiaries or partners in the west (U.S.A. and U.K. being primary destinations for investment funds), collected funds are used to acquire real estate and small companies that pass the above mentioned screens, or whose debt can be restructured to pass them (oftentimes through lease-based leveraged buy-outs, a popular western mergers and acquisitions tool of the 1980s and 1990s).

Taking into account data in the Capgemini-Merrill Lynch World Wealth Report (2009), there are around $\$ 2.5$ trillion of managed assets worldwide that are owned by Muslims, albeit nearly all of which must be conventionally managed since not even $\$ 100$ billion exists in Islamic mutual funds and Private Equity (murabaha and cash cannot be considered as managed assets). This indicates that Muslims have only placed 4\% of their managed assets into Shariah compliant investments, of which half is in mutual funds and half in Private Equity funds. Put it in another way, $96 \%$ of Muslim wealth is managed conventionally, and only $2 \%$ is invested in Islamic mutual funds. This reality can be taken as an extraordinary potential for growth.

Sandwick (2011) found that very large number funds are of a very small size, and that several hundred funds that initially appeared to be qualifying as mutual funds, cannot be considered as such.

\section{Islamic Banking versus Conventional Banking}

The main differences between Islamic Banking (an interest-free banking) model and the traditional interest-based banking model is that under the latter the level of interest is fixed in advance, whereas in the former the benefits (as well as the losses) are shared between the creditor and the borrower according to a formula that reflects their respective levels of participation. Thus, the profit-sharing concept implies an interest in the profitability of the "joint agreement or venture" on the part of the creditor (the bank). The emphasis is on the long-term success of the joint venture.

A crucial aspect of the capitalist system is the realization that the interest concept comprises two different perspectives: the time value of money (possibility that the borrower can generate profit using the money over the time he has the right to decide upon its application) and the risk value of money (the risk that the borrower will not repay it in due time: the credit risk). Before, 700 years ago was relevant the distinction between "usury" and "interest" as a factors of success for the development of finance to expand the economy.

An economy with an Islamic banking system is less vulnerable to business cycles, since there is a high correlation with the real economy and the level of risk spread between the bank and the entrepreneur in accordance with their respective participation. In an interest-based banking framework, the emphasis is on the short term.

Under a Western banking system, the rate of interest is a relevant variable to convey the nature and state of supply and demand; it embodies crucial information concerning the market, helping to reduce the search cost for alternative financing sources. In this sense the search for the most profitable option under Islamic Banking will most likely take longer and will probably be costly. The main differences and similarities between conventional and Islamic banks can be summarize as follows in table 6: 
Table 6. Main characteristics conventional banks and Islamic banks

\begin{tabular}{|c|c|}
\hline Conventional Financial Banks & Islamic Financial Banks \\
\hline Based on interest rate & Based on profit and losses sharing \\
\hline Provide hard cash as loan by charging interest & $\begin{array}{l}\text { Are not dealer of money hence no provision of } \\
\text { financing in hard currency is available }\end{array}$ \\
\hline $\begin{array}{l}\text { Can promise a predetermined return (risk free) to } \\
\text { depositors }\end{array}$ & Cannot promise of risk free return to depositors \\
\hline Are lenders of cash & $\begin{array}{l}\text { Are traders of goods and services ad not the } \\
\text { loan houses as for financing is concerned }\end{array}$ \\
\hline $\begin{array}{l}\text { Reduces the search cost for alternative financing } \\
\text { schemes }\end{array}$ & $\begin{array}{l}\text { The search for the most profitable option will } \\
\text { most likely take longer and will probably be } \\
\text { costly }\end{array}$ \\
\hline $\begin{array}{l}\text { Conveys the nature and state of supply and demand } \\
\text { of money }\end{array}$ & $\begin{array}{l}\text { does not readily provide a systematic } \\
\text { mechanism by which these profit shares are } \\
\text { arrived at }\end{array}$ \\
\hline Embodies information concerning the market overall & $\begin{array}{l}\text { An added cost to oversee projects in which they } \\
\text { are partners }\end{array}$ \\
\hline
\end{tabular}

Source: Authors Research

Nevertheless, there are some financial products that are common to both models of financial intermediation, as leasing (Ijara), or joint venture (Musharakah) while others are specific to each type of banking system as derivatives, credit default swaps and interest-based deposits for Conventional Banks or profit sharing (Mudharabah) and cost plus sale (Murabahah) for Islamic Banks Hassan and Dridi (2010).

Western bankers need to increase education and training to improve expertise and knowledge to develop Islamic financial instruments and the industry itself. Third, risk management is a vital part of conventional banking but there have been many problems in achieving this for the Islamic banking sector, mainly due to non acceptance by Muslim Scholars (Al-Omar, 2000). To develop this particular area, the International Swap and Derivatives Association have signed a Memorandum of Understanding with International Islamic Financial Market to develop Shariah compliant derivatives. Fourth, Karbhari et al (2004) identify that in order to prosper, Islamic banking needs to resolve the regulation by the Basel Committee's minimum capital and liquidity requirement and fifth, the support from the UK public, because Dar and Presley (2000) found that although Islamic banks offer Mudaraba (profit and loss shared) it is not used in practice and instead finance with mark-up (Murabaha) or leasing based financing (Ijara) is used. Both, Murabaha and Ijara services are similar to those found in conventional banks and eliminate the need for Islamic banks as they offer nothing unique. The lack of demand for these products will cause Islamic banks to stop offering them and restrict their growth in the UK.

In the meantime, as we have shown, market-based fixed-income alternatives have been available for quite some time based on securitization. Thus, Islamic finance clients can buy Islamic mortgage-based securities, or invest directly in pools of securitized fixed-return Islamic financial products. In this regard, while securitized Murabaha (cost-plus credit sale receivable) portfolios are deemed non-tradable except on face value, Islamic jurists have allowed trading mixed portfolios of sale-based and lease-based receivables, provided that the latter constitute at least $51 \%$. If the market for Islamic-finance assets continues to grow, the ability to offer all types of fixed-income instruments, including bank savings accounts, should become more common in the West.

So, we can conclude that Islamic banking and conventional banking are different in their philosophy as well as operations. Islamic banks are not dealer of money hence no provision of financing in hard currency is available while conventional banks are providing hard cash as loan by charging interest. Likewise Islamic banks cannot promise of risk free return to depositors while conventional banks are providing predetermined return (risk free) to depositors. Islamic banks are traders of goods and services while conventional banks are lenders of cash. This difference is being reflected at operational level as well. Islamic banks use financing tools being used in trade including Marabaha, Ijarah, Bai Salam, Bai Muajjal, Istisna'a and Musharaka. On the other hand if 
financing is required in cash form then Islamic banks are using profit and loss sharing modes including Musharaka and Mudaraba.

However it is interesting to point out that from July 2007 Sovereign Wealth Funds (SWFs) from countries like Abu Dhabi, Kuwait, Lybia, and Qatar made important investments in large western banks such as : Barclays, Citigroup, Credit Suisse, Merril Lynch, Morgan Stanley, UBS and Unicredit (Banque de France, 2008, p.12). Some of these investments represented 10 per cent or more of the capital of the banks, but it seems that they were made not for seeking control rights (effective control) then they cannot be qualified as foreign direct investment (FDI). However, this can be interpreted as cooperative investment type seeking for financial integration between Islamic and Western models.

\section{Islamic Banks and the Global Financial Crisis}

The principles of Islamic banks do not allow gambling on derivatives and prevent the excess of leverage; two factors underlying the current crisis. Islamic banks have showed greater resilience during the recent financial crisis as they were not involved in trading "toxic assets" showed, on average, stronger resilience (Dridi and Hasan, 2010). Another reason is that Islamic banks, in contrast to most conventional banks, tend to finance their activities out of deposits rather that from wholesale funding, and consequently are less subject to the volatility of the markets.

Some authors (Chapra, 2008; Siddiqi 2008, Kartika, et al 2010) defenders of Islamic finance attribute the crisis to inadequate market discipline, resulting from lack of using profit and loss sharing modes of financing, expansion of the types and size of derivatives and the policy of "too big to fail" (moral hazard). As debt cannot be traded because it can lead to riba, products like CDO/MBS would not exist in an Islamic system. Furthermore, derivative products like CDS are forbidden under Islamic law due to, among other reasons, the existence of gharar. As Islamic financial institutions were not exposed to the toxic securities that caused the crisis due to the Shariah prohibitions, they were not directly affected by the crisis.

An IMF Survey (2010) found that Islamic banks on average showed stronger reliance during the global financial crisis, but also found that when the crisis hit the real economy Islamic banks faced larger losses. The Dow Jones Indexes of both Industrial western and Islamic decreases significantly in the last quarter of 2008 due to the real economy crisis, that was explicated after the financial crisis was expanded since the end of 2007; in the first quarter of 2009 both indexes showed a positive growth rate to start again with a negative path in the last quarter of 2011 (when a new recession shows up again).

Nevertheless, this trend has not been followed by most of the Islamic Companies, as it shows by the results we obtained after carrying out a co-integration analysis between the Dow Jones Global Index and the Dow Jones Global for Islamic Firms during the period between January 2007 and December 2011.

It is said that a series $X_{t}$ is integrated of order $d(I(d))$ if the series becomes stationary after differencing $d$ times, and moreover, two or more time series are co-integrated if they share a common stochastic drift. If two or more series are individually integrated, for instance $I(1)$, and there exists some linear combination of them, whose has a lower order of integration $I(0)$, stationary process, then the series are said to be cointegrated. So, our goal is to check that two weekly Stock Market Series, Dow Jones Global Index and Dow Jones Global for Islamic Firms move through time together. First, we analyze a univariate time series model to prove that both series are first-order integrated. Looking at their periodograms we can confirm that both series have non-stationary means and variances, and there exists just a long run trend (Frequency $=0$ ). However, after integrating and fitting an ARIMA model, errors seem to be non-stationary. If we observe both series in levels, it is possible to detect some outliers which are concealing the fitted model. These values are:

Outliers Dow Jones Global Index:

\begin{tabular}{|c|c|c|c|c|c|c|}
\hline & & & Estimate & STE & $\mathrm{t}$ & Sig. \\
\hline \multirow[t]{2}{*}{ DJ_GLOBAL } & 93 & Change of level & -42.240 & 6.537 & -6.461 & .000 \\
\hline & 99 & Additive & -16.940 & 4.623 & -3.665 & .000 \\
\hline
\end{tabular}


Outliers Dow Jones Islamic Global:

\begin{tabular}{|c|c|c|c|c|c|c|}
\hline & & & Estimate & STE & $\mathrm{t}$ & Sig. \\
\hline \multirow[t]{6}{*}{ DJ_ISL } & 92 & Change of level & -189.590 & 49.506 & -3.830 & .000 \\
\hline & 93 & Change of level & -335.220 & 49.506 & -6.771 & .000 \\
\hline & 95 & Additive & -136.605 & 35.006 & -3.902 & .000 \\
\hline & 99 & Additive & -127.270 & 35.006 & -3.636 & .000 \\
\hline & 240 & Change of level & -200.190 & 49.506 & -4.044 & .000 \\
\hline & 256 & Additive & -135.280 & 35.006 & -3.864 & .000 \\
\hline
\end{tabular}

$93^{\text {rd }}$ week corresponds with Lehman Brothers bankruptcy. Regarding both series we can confirm that Islamic Dow Jones has got more volatility than Global Dow Jones. After filtering series by outliers, errors confirm to be random walk. In order to assure that both series are first-order integrated we compute Augmented Dickey-Fuller Test, getting (In log-levels):

\begin{tabular}{lllll}
\hline DJ_Global & & & \\
\hline ADF Test Statistic & $\mathbf{- 1 . 4 3 6 . 5 8 4}$ & $1 \%$ & Critical Value* & -39.976 \\
& & $5 \%$ & Critical Value & -34.288 \\
& & $10 \%$ Critical Value & -31.376 \\
DJ_Isl & & & \\
ADF Test Statistic & $\mathbf{- 1 . 5 0 0 . 7 4 9}$ & $1 \%$ & Critical Value* & -39.976 \\
& & $5 \%$ & Critical Value & -34.288 \\
& & $10 \%$ Critical Value & -31.376 \\
\hline
\end{tabular}

Differencing:

\begin{tabular}{lllll}
\hline DJ_Global & & & \\
\hline ADF Test Statistic & $\mathbf{- 6 . 6 8 7 . 4 6 4}$ & $1 \%$ & Critical Value* & -34.580 \\
& & $5 \%$ & Critical Value & -28.731 \\
& & $10 \%$ Critical Value & -25.729 \\
DJ_Isl & & & \\
ADF Test Statistic & $\mathbf{- 6 . 8 1 5 . 1 7 3}$ & $1 \%$ & Critical Value* & -34.580 \\
& & $5 \%$ & Critical Value & -28.731 \\
& & $10 \%$ Critical Value & -25.729 \\
\hline
\end{tabular}

Since the ADF Test is more significative than before, both series are first-order integrated, rejecting the null hypothesis. Then, it seems to be appropriate to look for a linear combination that makes errors be stationary. 
Dependent Variable: DJ_Is1

Method: Least Squares

Included observations: 264

\begin{tabular}{lllll}
\hline Variable & Coefficient & Std. Error & t-Statistic & Prob. \\
\hline C & 0.000229 & 3.580 .053 & $6.39 \mathrm{E}-05$ & 0.9999 \\
DJ_GLOBAL & $\mathbf{5 . 8 0 7 . 2 2 2}$ & 0.311621 & 1.863 .551 & $\mathbf{0 . 0 0 0 0}$ \\
\hline R-squared & 0.569986 & Mean dependent var & & -0.000871 \\
Adjusted R-squared & 0.568345 & S.D. dependent var & & 8.853 .660 \\
S.E. of regression & 5.816 .898 & Akaike info criterion & & 1.097 .213 \\
Sum squared resid & 886511.0 & Schwarz criterion & & 1.099 .922 \\
Log likelihood & -1.446 .321 & F-statistic & & 3.472 .823 \\
Durbin-Watson stat & $\mathbf{0 . 5 8 5 2 6 1}$ & Prob(F-statistic) & & 0.000000 \\
\hline
\end{tabular}

Dependent Variable: DJ_Isl

Method: Least Squares

Included observations: 264

\begin{tabular}{lllll}
\hline Variable & Coefficient & Std. Error & t-Statistic & Prob. \\
\hline C & 0.000229 & 3.580 .053 & $6.39 \mathrm{E}-05$ & 0.9999 \\
DJ_GLOBAL & $\mathbf{5 . 8 0 7 . 2 2 2}$ & 0.311621 & 1.863 .551 & $\mathbf{0 . 0 0 0 0}$ \\
\hline R-squared & 0.569986 & Mean dependent var & & -0.000871 \\
Adjusted R-squared & 0.568345 & S.D. dependent var & & 8.853 .660 \\
S.E. of regression & 5.816 .898 & Akaike info criterion & & 1.097 .213 \\
Sum squared resid & 886511.0 & Schwarz criterion & & 1.099 .922 \\
Log likelihood & -1.446 .321 & F-statistic & & 3.472 .823 \\
Durbin-Watson stat & $\mathbf{0 . 5 8 5 2 6 1}$ & Prob(F-statistic) & & 0.000000 \\
\hline
\end{tabular}

At a 5\% significance level, DJ_Global seems to be significant different from 0 , so we reject the null hypothesis. And, $R^{2}<D W$, so we are sure that there is not a spurious regression. To study co-integration, we state the CRDW Test:

$H_{0}: D W=0 \mathrm{~N}$ on-cointegrated variables

$H_{1}: D W>0$ Cointegrated variables

Regarding at critical value $(\mathrm{CV})$, at $5 \%$ significance level $C V=0.386$, so we affirm that: $D W=0.5852>0.386$, then both series are co-integrated. Once we have checked that series are co-integrated, we express in terms of Error Correction Model. This model is a dynamical model with the characteristics that the deviation of the current state from its long-run relationship will be fed into its short-run dynamics 
Dependent Variable: DDJ_ISL

Method: Least Squares

Included observations: 263 after adjusting endpoints

\begin{tabular}{lllll}
\hline Variable & Coefficient & Std. Error & t-Statistic & Prob. \\
\hline DDJ_GLOBAL & 5.450 .882 & 0.329917 & 1.652 .199 & 0.0000 \\
RRES2 & $\mathbf{- 0 . 2 9 2 7 3 7}$ & 0.043702 & -6.698 .473 & 0.0000 \\
\hline R-squared & 0.546554 & Mean dependent var & & 0.624677 \\
Adjusted R-squared & 0.544817 & S.D. dependent var & & 6.090 .757 \\
S.E. of regression & 4.109 .267 & Akaike info criterion & & 1.027 .711 \\
Sum squared resid & 440726.5 & Schwarz criterion & & 1.030 .428 \\
Log likelihood & -1.349 .440 & Durbin-Watson stat & & 1.851 .196 \\
\hline
\end{tabular}

Where -0.292737 is the co-integration parameter.

Besides, in order to study causality, we state the Granger Causality Test, and we get:

Pairwise Granger Causality Tests

Lags: 15

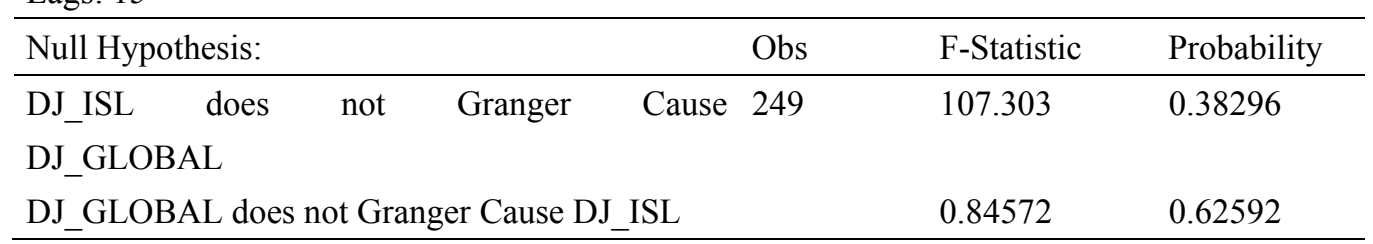

Being confirmed that neither Dow Jones Global Index causes Dow Jones Islamic Global behavior nor Dow Jones Islamic Global causes Dow Jones Global Index tendency, then it can be said that both of them move through time at one.

However, if the key factors causing the crisis can be identified at three levels: a deregulated environment, financial institutions engaged in excessive risk-taking and the use of innovative complex products, Ahmed (2009) argues that when the practice of Islamic finance and the environment under which it operates are examined, one can identify trends that are similar to the ones caused the current crisis. Perhaps this conclusion is related to the tendency of some conversion of Islamic banks towards western banks in long term financing and the issuing of new products, however not related to what is considering gambling (derivatives, risk taking).

At the institutional level, the regulatory standards for the Islamic financial sector are in elementary stages, weak and still evolving. Thus, the regulatory restraints on Islamic financial institutions are expected to be no better than their conventional counterparts. At the organizational level, it is difficult to prevent excessive profit seeking and risk taking in Islamic banks unless their Boards of Directors and management impose prudent risk-management practices, and finally, the Islamic financial industry has witnessed rapid growth with innovations of complex Shariah compliant financial products. Risks in these new Islamic financial products are complex as the instruments have multiple type of risk and they evolve and change at different stages of transactions. As the risks of Islamic financial products are not easy to comprehend, it may be difficult to control them.

\section{Conclusions}

The basis for Islamic finance lies in the principles of the Shariah, the Islamic Law. Halal (permissible) and Haram (forbidden) provide a moral filter both for all human actions and for the economic system as a whole. Interest (known as riba) is forbidden as well as activities with gharar (excessive or unquantifiable risks: Islamic banks are not allowed gambling on derivatives). Savings are not rewarded on a fixed rate but on variable reward based on actual return shared (profit and loss sharing principle) with the investor. Gharar's prohibitions include gambling, pork production, alcohol or any business that have to pay or charging of interest, as well as to finance investments in the future based on conditions that are not certain to occur, associated to currently non-existent collateral and property, casualty or life insurance. Then, under this conception Islam would prefer to promote an 
equity-based, risk sharing, and stake-taking economic system to a debt-based system (preventing the excess of leverage). An economy with an Islamic banking system should be less vulnerable to business cycles, since there is a high correlation with the real economy and the level of risk spread between the bank and the entrepreneur in accordance with their respective participation.

Within the last years, the Islamic Finance Industry has witnessed both quantitative and qualitative developments, which necessitated the emergence of supportive institutions for the industry so as to highlight the cultural aspects of Muslims in the field of economics. The potential of Islamic banking is increasing the depth and breadth of the banking system and making it more diverse and stable. However, future development and promotion of the industry can play a greater role in the economic development and capital formation of Islamic countries but a further effort is needed to provide the right framework.

The development and growth of Islamic banks have play an active role in the process of generating new formal institutions both external and exogenous (regulations, organizations, international treaties and agreements) and new internal or endogenous (new financial instruments, changing political regimes). Also traditional (western type) banks have also adopted new internal institution to operate in the Islamic world, creating Islamic division or subsidiaries working in a new environment with specific external institutions. In this perspective it seems that as Morgan (2005) said the dynamic analysis of an international firm needs to consider in parallel the dynamic view of institutions.

There is a lack of harmonized accounting and regulatory standards (local accounting standards used in the Islam banking sector often consist of a mixture of different types of international standards). The Islamic countries have to make an effort to provide the right frame for carrying out the mentioned institutional development, improving their legal and regulatory frameworks. The international financial and economic crisis also pointed out that that a comprehensive regulatory architecture for the Islamic financial sector is needed.

Understanding Islamic banking is essential from a financial stability perspective. The lack of developed markets in which Islamic financial instruments can be traded is one of a number of problems caused by lack of cooperation among Muslim financial institutions. There is a shortage of recognized instruments, and the legitimate use of each instrument is also a subject of dispute. The further growth and development of the Islamic financial system will depend largely on the nature of innovations introduced not only in the market but specially in institutions, national and to the Islamic system. Further growth and development of the Islamic financial system will depend largely on the nature of innovations introduced in the market. Recent products, such as Sukuks (Islamic bonds) help to meet liquidity requirements and consequently reinforce to develop the market. The institutional development of Islamic institutions to be applying to the Islamic world and to cooperate with Multilateral organizations are aimed to underlying financial and economic integration not only among the Muslim world but also between this and the western model. Countries where both models coexist may play an important role. The Islamic financial centers (Dubai, Malaysia..) play a certain role in the internationalization of financial markets from ant to Islamic countries.

Member countries not only develop transnational institutions but also implement them. At the same time national states are actors of multiple policy networks that produces all kinds of rules (explicit and tacit) governing economic activity. Such rules are often "soft law" (standards, norms, guidelines) that often marginalize domestic political processes and interest groups (Djelic and Sahlin-Andersson, 2006). Co-evolution studies have the potential to serve as unifying framework for research about under what conditions new organizational forms are likely to emerge (Lewin and Volbverda, 1999). Future research on political dynamics of Islamic institutions is needed.

"With tolerance and understanding it is possible for western and Islamic style economic systems to exist side by side, with each retaining its own unique characteristics" (Dunning, 2002:4). "This would make the global society a matrix where different cultures and systems can co-exist" Ahmed, 2002: )

\section{References}

Aggarwal, R.K., \& Yousef, T. (2000). Islamic Banks and Investment Financing. Journal of Money, Credit and Banking, 32(1), 93-120. http://dx.doi.org/10.2307/2601094

Ahmed, H. (2009). Financial Crisis: Risk and Lessons for Islamic Finance. International Journal of Islamic Finance, 1(1), 7-32.

Ahmed, K. (2002). The Challenge of Global Capitalism: An Islamic Perspective. In Dunning, J.H. (Ed.), Making Globalization Good. The Moral Challenges of Global Capitalism. Oxford University Press. Oxford.

Ahmed, Z. (1994). Islamic banking: state of the art. Islamic Economic Studies, 2(1), 1-34. 
Al-Omar. (2000). Islamic banks and investment financing. Journal of Money, Credit and Banking, 32(1), 93-120. http://dx.doi.org/10.2307/2601094

Askari, H., Iqbal, Z., \& Mirakhor, A. (2009). Expanding Financial Frontiers - Part 1. Islamic Financial News, $6(21)$.

Banker. (2010). Top $500 \quad$ Islamic Institutions. Retrieved from http://www.thebanker.com/Markets/Islamic-Finance/Top-500-Islamic-Financial-Institutions2

Brooks, A. (1999). Repo market crosses line in the sand. International Securities Lending (pp37-40). London. Pages.

Cantwell, J., Dunning, J.H., \& Lundan, S.M. (2010). An evolutionary approach to understanding international business activity: the co-evolution of MNE's and the institutional environment. Journal of International Business Studies, 41, 567-586. http://dx.doi.org/10.1057/jibs.2009.95

Casson, M.C., \& Lundan, S.M. (1999). Explaining international differences in economic institutions: A critique of the "national business system" as an analytical tool. International Studies of Management \& Organization, 29(2), 25-42.

Chapra, U. (2008). The Global Financial Crisis and the Islamic Financial System. Paper presented at the Forum on the Global Financial Crisis, Islamic Development Bank.

Dar, H. A., \& Presley J. R. (2000). Lack of Profit Loss Sharing in Islamic Finance: Management and Control Imbalances. International Journal of Islamic Financial Services, 2(2), 1-16.

Djelic, M.L., \& Sahlin-Andersson, K. (Eds.). (2006). Transnational Governance: Institutional Dynamics of Regulation. Cambridge, Cambridge University Press.

Dridi, J., \& Hassan, M. (2010). Have Islamic Banks Been Impacted Differently than Conventional Banks During the Recent Global Crisis?. International Monetary Fund. Working Paper 10/201. Washington. Retrieved from http://www.cibafi.org/pdf/IMF_Paper_Sept2010.pdf

El Gamal, M. (2006). "Overview of Islamic Finance" Department of the Treasury Office of International Affairs. Occasional Paper No. 4. August 2006. Retrieved from http://www.nzibo.com/IB2/Overview.pdf

Elwaleed, M. A. (2007). Sukuk "Islamic Bond" The Fastest Growing Sector in Islamic Finance: Its Unique Feature \& The Challenges Facing Its Growth. Retrieved from http://sukukislamicbond.blogspot.com

Ernst \& Young. (2010). World Takaful Report. Retrieved from http://www.ey.com/Publication/vwLUAssets/EY_WTR_2010/\$FILE/EY_WTR_2010.pdf

Hearn, B., Piesse, J., \& Strange, R. (2012). Islamic finance and market segmentation: Implications for the cost of capital. International Business Review, 21, 102-113. http://dx.doi.org/10.1016/j.ibusrev.2010.11.007

Iqbal, M., \& Molyneux P. (2005). Thirty Years of Islamic Banking: History, Performance and Prospects. Islamic Economic, 19(1), 37-39.

Islamic Development Bank (IDB). (2009). Enhancing Capital Markets Cooperation among IDB Member Countries. Retrieved from http://www.isdb.org/irj/go/km/docs/documents/IDBDevelopments/Internet/English/IDB/CM/Publications/C apitalMarketCooperation.pdf

Jackson, G., \& Deeg, R. (2008). Comparing capitalism: Understanding institutional diversity and its implications for international business. Journal of International Business Studies, 39(4), 540-561. http://dx.doi.org/10.1057/palgrave.jibs.8400375

Karbhari, Y., Naser, K., \& Shahin, Z. (2004). Problems and Challenges Facing the Islamic Banking System in the West: The case of UK. Thunderbird International Business Review, 46(5), 521-543. http://dx.doi.org/10.1002/tie.20023

Kartika, M., \& Reza, I. (2010). Islamic Finance: A Therapy for healing the global financial crisis. Working Paper. Bank Muamalat Indonesia.

Kay, W. (2004). "FSA approves first purely Islamic bank" The Independent. 9 August, 2004. Retrieved from http://www.independent.co.uk/news/business/news/fsa-approves-first-purely-islamic-bank-555932.html.

Lewin, A.Y., \& Volberda, H.W. (1999). Prolegomena on Coevolution: A Framework for Research on Strategy and New Organizational Forms. Organization Science, 10(5), (September-October) 519-534. http://dx.doi.org/10.1287/orsc.10.5.519 
Malik, M.S., Malik, A., \& Waqas, M. (2011). Controversies that make Islamic banking controversial: An analysis of issues and challenges. American Journal of Social and Management Sciences, 2(1), 41-46. http://dx.doi.org/10.5251/ajsms.2011.2.1.41.46

Mills, P.S., \& Presley, J.R. (1999). Islamic Finance: Theory and practice. London: Macmillan. http://dx.doi.org/10.1057/9780230288478

Moody's. (2008). Islamic Finance Explores New Horizons in Africa. Retrieved from http://www.institutfrancaisdefinanceislamique.fr/docs/docs/doc_id85.pdf

Morgan, G. (2005). Introduction: Changing capitalism? Internationalization, institutional change, and systems of economic organizarion. In G. Morgan, R. Whitley and E. Moen (Eds.), Changing capitalisms? Internationalization, institutional change, and systems of economic organization. Oxford University Press. Oxford, pp. 1-18

Nelson, R.R. (2008). What enables rapid economic progress: What are the needed institutions? Research Policy, 37(1), 1-11. http://dx.doi.org/10.1016/j.respol.2007.10.008

Nelson, R.R., \& Sampat, B.N. (2001). Making sense of institutions as factor shaping economic performance. Journal of Economic Behavior \& Organization, 44(1), 31-54. http://dx.doi.org/10.1016/S0167-2681(00)00152-9

Nelson, R.R., \& Winter, S.G. (1982). An Evolutionary Theory of Economic Change. Ed. Harvard Collegue.

North, D.C. (1990). Institutions, institutional change and economic performance. Cambridge: Cambridge Press. http://dx.doi.org/10.1017/CBO9780511808678

North, D.C. (2005). Understanding the process of economic change. Princeton. New Jersey: Princeton University Press.

Oakley, D. (2009). London leads in race to be western hub. The Financial Times, 8 December, 2010 page 4.

Ray, N. (1999). Arab Islamic Banking and the Renewal of Islamic Law. Islamic Economics, 11, 63-69. Retrieved from http://islamiccenter.kau.edu.sa/arabic/Magallah/Pdf/11/11-Kamali_08.pdf

Sandwick, J. (2011). Islamic Asset Management: Impotence and Potential. Retrieved from http://www.islamica-me.com/article.asp?cntnt=639

Siddiqui, M.N. (2008). Current Financial Crisis and Islamic Economics. Mimeo. Retrieved from http://aawad.kau.edu.sa/Files/121/Researches/55495_25818.pdf\#page $=5$

Simon, H. (1957). "A Behavioral Model of Rational Choice", in Models of Man, Social and Rational: Mathematical Essays on Rational Human Behavior in a Social Setting. New York: Wiley.

Solé, J. (2008). Introducing Islamic Banks into Conventional Banking Systems. Journal of Islamic Economics, Banking and finance. Retrieved from http://www.ibtra.com/pdf/journal/v4_n2_article1.pdf

Standard, \& Poors. (2009). Sukuk comes of Age in Infraestructure and Project Finance - Part I. Retrieved from http://kantakji.com/fiqh/Files/Markets/f195.pdf

Taylor, J.B. (2007). Global financial warriors: the untold story of international finance in the post-9/11 world. ( $1^{\text {st }}$ ed.). Norton. New York.

UKTI. (2008). UK committed to Islamic banking. Retrieved from http://www.ukinvest.gov.uk/OurWorld/4032380/en-GB.html

Usmani, M.T. (2008). Islamic Finance: Musharakah \& Mudarbah. Journal of Islamic Banking and Finance, 25(3), 41-53.

Zaher, T.S., \& Hassan, K. M. (2001). A Comparative Literature Survey of Islamic Finance and Banking. Financial Markets, Institutions \& Instruments, 10(4), 155-198. http://dx.doi.org/10.1111/1468-0416.00044

Zarqa, M.A. (1983). Stability in an Interest-free Islamic economy: a note. Pakistan Journal of Applied Economics, 2(winter), 181-188. 


\section{Notes}

Note 1. We must remark that most of Islamic countries got the independence during 50's and 60's (see annex I), and most of them had been colonized by United Kingdom and France.

Note 2. Shariah advisors are practicing as an independent body with the responsibility of issuing Shariah rulings or fatwa to the various issues in the Islamic banking and finance industry.

Note 3. However according to the study of Aggarwal and Yusef (2000) most of the financing provided by Islamic banks do not conform to the principle of profit-and-loss sharing. Much of the contracts are offered through debt-like instruments. In some cases they use complex formulas to implement the principle of PLS.

Note 4. In general it has been observed that economic transformation of a society can be explained by the co-evolution of technology and institutions (Nelson 2002).

Note 5. MNEs can introduce institutional elements that are not available in the local environment (Peng et al., 2008) and may get involve in political issues to overcome the lack of regulation and of markets for intermediate products.

Note 6 Kay (2004) said about the history of Islamic banks in UK by narrating that the first Islamic bank to operate in the UK was in the early 1980's: Al-Baraka bank (Bahrain), which acquired Hardgrave Securities to serve high net worth Arabs who spent the summer in London. The bank offered for the first time to Muslims in the UK investment deposit facilities on a Mudaraba basis. The increase in demand from 1983 to 1991 of 223 million to $£ 150$ million showed that clearly the demand for Islamic banking within the UK was evident.

Note 7. In the late 1990s Dow Jones, and later Financial Times, launched their Islamic indices. After other Islamic indices were added, paralleling their conventional indices, but they include a smaller universe of equity securities. 
Annex I: Number of Islamic Banks 2001 / 2011

\begin{tabular}{|c|c|c|}
\hline Country & Islamic Banks 2001 & Islamic Banks 2011 \\
\hline Abu Dhabi & 0 & 3 \\
\hline Algeria & 1 & 3 \\
\hline Azerbaijan & 0 & 1 \\
\hline Bahamas & 1 & 0 \\
\hline Bahrain & 4 & 24 \\
\hline Bangladesh & 2 & 7 \\
\hline Bosnia & 0 & 1 \\
\hline Brunei & 0 & 1 \\
\hline Cyprus & 0 & 1 \\
\hline Dubai & 0 & 6 \\
\hline Egypt & 1 & 2 \\
\hline Ethiopia & 0 & 1 \\
\hline Gambia & 0 & 1 \\
\hline Indonesia & 0 & 4 \\
\hline Iran & 0 & 17 \\
\hline Iraq & 0 & 3 \\
\hline Jordan & 2 & 3 \\
\hline Kazakhastan & 0 & 1 \\
\hline Kenya & 0 & 2 \\
\hline Kuwait & 1 & 5 \\
\hline Labuan & 0 & 1 \\
\hline Lebanon & 0 & 3 \\
\hline Malaysia & 3 & 25 \\
\hline Maldivas & 0 & 1 \\
\hline Mauritania & 0 & 1 \\
\hline Mauritius & 0 & 1 \\
\hline Niger & 0 & 1 \\
\hline Nigeria & 0 & 1 \\
\hline Pakistan & 0 & 6 \\
\hline Palestine & 0 & 3 \\
\hline Philippines & 0 & 1 \\
\hline Qatar & 2 & 6 \\
\hline Russia & 0 & 1 \\
\hline Saudi Arabia & 0 & 5 \\
\hline Senegal & 0 & 1 \\
\hline
\end{tabular}




\begin{tabular}{lcc}
\hline UAE & 2 & 1 \\
Singapore & 0 & 1 \\
Somalia & 0 & 3 \\
South Africa & 0 & 1 \\
Sudan & 1 & 16 \\
Switzerland & 0 & 1 \\
Syria & 0 & 3 \\
Thailand & 0 & 1 \\
Tunisia & 0 & 2 \\
Turkey & 0 & 4 \\
Turkish Cyprus & 0 & 1 \\
Uganda & 0 & 1 \\
United Kingdom & 0 & 5 \\
United States & 0 & 2 \\
Yemen & 2 & 5 \\
TOTAL & $\mathbf{2 2}$ & $\mathbf{1 9 0}$ \\
\hline
\end{tabular}

Source: Bankscope (2002) and Association of Islamic Banks Institutions Malaysia (2011) and authors research

Annex 1I. Year of Independence of Islamic Countries

COUNTRY YEAR OF INDEPENDENCE COLONIZER

EAST AFRICA

Uganda

1962

U.K.

\section{WEST ASIA}

Bahrain

1971

U.K.

Jordan

1957

U.K.

Kuwait

1961

U.K.

Lebanon

1943

Qatar

1971

FRANCE

Saudi Arabia

1927

Syria

1946

Turkey

1923

United Arab Emirates

1971

U.K.

Yemen

1918 / 1967

U.K.

FRANCE

OTOMAN EMPIRE

U.K.

OTOMAN EMPIRE /

U.K.

\section{SOUTH ASIA}

Bangladesh

1971

PAKISTAN 
Iran

Pakistan

SOUTH EAST ASIA

Brunei

1984

Indonesia

Malaysia

CIS

Kazakhistan

1991
U.K.

HOLANDA

U.K.

URSS

NORTH AFRICA

Algeria

1962

Egypt

1932

Libya

1951

Morroco

1956

Sudan

1956

Tunisia

\section{WEST AFRICA}

Benin

1960

Burkina Faso

1960

Mali

1960

Mauritania

1958

Níger

1960

1960

Senegal

\section{CENTRAL AFRICA}

Cameroon

1972

Chad
FRANCE

U.K.

U.K.

FRANCE AND SPAIN

U.K.

U.K.

FRANCE

FRANCE

FRANCE

FRANCE

U.K.

FRANCE

FRANCE/U.K.

FRANCE 


\section{Annex III. Main Islamic Banking and Finance Organizations}

The Union of Arab Banks

http://www.uabarablaws.org/

Islamic Development Bank

http://www.isdb.org/index.html

Arab Monetary Fund

http://www.amf.org.ae/aboutamf

Islamic Research and Training Institute

(IRTI) http://www.irti.org

Gulf Cooperation Council

http://www.gcc-sg.org/

International Association of Islamic

Economics (IAIE) http://www.iaie.net

Institute of Islamic Banking and

Insurance

http://www.islamic-banking.com/Default aspx

Accounting and Auditing Organisation for Islamic Financial Institutions $\underline{\text { http://www.aaoifi.com/aaoifi/default.asp }}$ $\underline{\mathrm{x}}$

Islamic Corporation for Insurance of
Founded in 1974. The organization seeks to be a referral centre for the Arab financial and banking community; to foster its member ties with each other; strengthen their bonds of cooperation; coordinate their activities; and defend their interests; to develop the Arab financial thought and banking industry on sound and sustainable basis and to be a bridge for Arab banks to the international banking business rules with a view to facilitating and promoting their integration into the global financial and banking.

Founded in 1975. The purpose of the Bank is to foster the economic development and social progress of member countries and Muslim communities individually as well as jointly in accordance with the principles of Shariah i.e., Islamic Law.

Founded in 1976. Its objectives could be summarized on:

- Providing short-term and medium-term credit facilities.

- Liberalizing and promoting trade and the resulting current.

- Allocating from its resources, paid in the currencies of the member States, sufficient funds to provide the necessary credits to settle their current payments among them.

- Managing any funds placed under the charge of the Fund by a member State or States.

Founded in 1981. The institute is an affiliate of the Islamic Development Bank Group responsible for leading the development and sustenance of a dynamic and comprehensive Islamic Financial Services Industry that supports socio-economic development in Member countries.

Founded in 1981. The GCC Charter states that the basic objectives are to effect coordination, integration and inter-connection between Member States in all fields, strengthening ties between their peoples, formulating similar regulations in various fields such as economy, finance, trade, customs, tourism, legislation, administration, as well as fostering scientific and technical progress in industry, mining, agriculture, water and animal resources, establishing scientific research centers, setting up joint ventures, and encouraging cooperation of the private sector.

Founded in 1984. The IAIE is as an educational and professional organization with the objective of promoting the study and application of Islamic economics, banking and finance. It evolves the reconstruction of economic and finance theory and practice in the light of Islamic principles

Founded in 1990. Its objective is to pursue original research and effective learning and teaching of international distinction and impact in building a wider knowledge base and a deeper understanding of world of finance based on the principles emphasized in Islamic economics that promote equity, socio-economic justice and inclusiveness in all dealings.

Founded in 1991. The Accounting and Auditing Organization for Islamic Financial Institutions (AAOIFI) is an Islamic international autonomous non-for-profit corporate body that prepares accounting, auditing, governance, ethics and Shariah standards for Islamic financial institutions and the industry. Founded in 1994. Its objective is to encourage Exports from Member 
Investments and Export Credits (ICIEC) http://www.iciec.com/

Islamic Corporation for the Development of the Private Sector http://www.icd-idb.org/

General Council for Islamic Banks and Financial Institutions http://www.cibafi.org/NewsCenter/Englis h/Default.aspx

International Islamic Financial Market http://www.iifm.net/

Islamic Financial Services Board http://www.ifsb.org
Countries and to facilitate the flow of Foreign Direct Investment to Member Countries by providing and encouraging the use of Shariah compatible Export Credit and Investment Insurance as Credit and Country Risk mitigation instruments.

Founded in 1999. ICD is a multilateral organization, affiliated with the Islamic Development Bank (IDB) Group. Its shareholders are the IDB, 45 Islamic member countries, and 5 public financial institutions from member countries. The mandate of ICD is to support economic development of its member countries through provision of finance to private sector projects in accordance with principles of the Shariah through promoting private sector development. ICD also provides advice to governments and private organizations to encourage the establishment, expansion and modernization of private enterprises.

Founded in 2001. The General council for Islamic Banks and Financial Institutions was established for two major roles: support and protect the industry. Support the industry through awareness and training, holding conferences, seminars and forums and providing the necessary information. Protect the industry so as to avoid, as much as possible, the obstacles and deviations in the course of the Islamic finance industry.

IFM was founded in 2002. Its main goals are: Addressing the standardization needs of the industry; providing universal platform to market participants through 'Global Working Groups' for the development of Islamic Capital and Money Market; Shariah harmonization in documentation, products and processes and Shariah Advisory Panel consisting of renowned scholars, hence, ensuring wider Shariah acceptance

Founded in 2002. The board has many objectives like to promote the development of a prudent and transparent Islamic financial services industry through introducing new, or adapting existing, international standards consistent with Shariah principles, and recommending these for adoption in addition to provide guidance on the effective supervision and regulation of institutions offering Islamic financial products.

Source: Authors Research 